\title{
Levels of Road Traffic Heavy Metals in Tree Bark Layers of Cassia fistula Tree
}

\author{
Rungruang Janta, Somporn Chantara, Angkhana Inta, Munetsugu Kawashima, and Kenichi Satake
}

\begin{abstract}
Use of vegetation as a bioindicator of atmospheric heavy metal accumulation has received more attention worldwide due to the fact that this method has been found to be effective, cheap and simple to use. This study aims to find out the levels of heavy metals found in tree bark layers and to test the factors (exposed sides of tree to traffic and size of tree trunk) that affect atmospheric heavy metal accumulation in the bark of Cassia fistula, which is a common tree commonly found along the road sides and planted for shading and decoration. In order to provide the necessary information with regard to using a native tree species as a bioindicator, heavy metals emitted from road traffic including $\mathrm{Cr}, \mathrm{Cu}, \mathrm{Fe}, \mathrm{Ni}, \mathrm{Pb}$ and $\mathrm{Zn}$ were investigated. The results showed that only $\mathrm{Cu}, \mathrm{Fe}$ and $\mathrm{Zn}$ were detected. Their concentrations were highest in the cork layer, decreased in the second (chlorenchyma), third (phloem) layers and increased in the innermost layer (vascular cambium). Heavy metals found on the outer most layer of bark definitely came from atmospheric pollution due to direct exposure to the environment. However, the concentrations in the vascular cambium were higher than in the chlorenchyma and phloem. This is probably due to some diffusion that took place in the xylem, which is connected to the cambium layer. Concerning the factors affecting the heavy metal accumulation in the tree bark, the size of Cassia fistula tree trunks $(5-30 \mathrm{~cm})$ was not significantly correlated $(p>0.05)$ with the heavy metal concentrations found in the bark. This was also true of the sides of the exposure of the tree in relation to the traffic source. This means that the bark sampling can be done easily without any limitations with regard to the size of tree trunk and direction of exposure.
\end{abstract}

Index Terms-Tree bark, heavy metal, bioindicator, Cassia fistula, atmospheric pollution.

\section{INTRODUCTION}

Heavy metals including $\mathrm{Cr}, \mathrm{Cu}, \mathrm{Fe}, \mathrm{Pb}$ and $\mathrm{Zn}$ are important pollutants in urban areas and their levels are directly related to the number of motor vehicles present [1]; [2]. The most toxic form of heavy metals is likely found to be the atmospheric contaminants either because of the great quantity involved or the widespread dispersion of these

Manuscript received April 20, 2015; revised June 26, 2015.

Rungruang Janta and Munetsugu Kawashima are with Environmental Science Program, Faculty of Science, Chiang Mai University, Chiang Mai 50200, Thailand (e-mail: rrjanta@yahoo.com).

Somporn Chantara is with Environmental Science Program, Faculty of Science, Chiang Mai University, Chiang Mai 50200, Thailand. Somporn Chantara is also with Chemistry Department, Faculty of Science, Chiang Mai University, Chiang Mai 50200, Thailand (e-mail: somporn.chantara@cmu.ac.th).

Angkhana Inta is with the Department of Biology, Faculty of Science, Chiang Mai University, Chiang Mai 50200, Thailand.

Kenichi Satake is with the Faculty of Geo-Environmental Science, Rissho University, Saitama 3600194, Japan. contaminants, which may originate from many different exposure pathways [3]. Recently, the sheer volume of vehicles in Asian countries has been increasing annually. Consequently, the monitoring of heavy metals emitted through road transportation has become necessary, particularly in mega cities.

The biomonitoring of tree bark is significant interest because it is cheap, easy and there are many choices of tree species. Examples of the trees species that have been successfully used to monitor the levels of aerial heavy metals were Fraxinus pennsylvanica [4], Pinus massoniana L. [5], Azadirachta indica [6], Casuarina equisetifolia and Delonix regia [7]. Since the most important criteria in the selection of a bioindicator is common occurrence [8], the species of the selected tree is specific to the study area in terms of the abundance of the tree species present. Moreover, most of the studies concerned with the use of trees as a bioindicator have been conducted in Europe and a number of other developed countries. In Southeast Asia and other tropical zones, the criteria used for the selection and the sampling of the trees in terms of environmental quality assessment is still fairly limited. This study aims to determine the levels of heavy metals present in the tree bark layers and to test the factors affecting heavy metal accumulation in the tree bark. Cassia fistula tree was selected for this study because it is a common tree species in Southeast Asia and the Indian subcontinent. In Thailand, this tree is widely found along roadsides and is often planted for the purposes of shading and decoration. The principle benefit of this study is to provide useful information regarding the sampling criteria for the use of native tree species as bioindicators of atmospheric heavy metal accumulation in tropical zones.

\section{MATERIAL AND METHOD}

\section{A. Site Location}

The study area is in the City of Chiang Mai, a metropolitan city in the northern region of Thailand. Chiang Mai is considered a tourist city and has attracted over 7 million visitors annually [9].This urban area is rapidly growing, as is the number of registered vehicles in the urban center. The samples were collected from 20 roadside trees along two main roads (Manee Nopparat Road and Huay kaew Road) in the city of Chiang Mai.

\section{B. Sampling Tree and Method}

The trees with a measured diameter at breast height (DBH) ranging from $21-30 \mathrm{~cm}$ were selected. The samples were selected from roadsides with less than $3 \mathrm{~m}$ distance from the 
road. The bark was removed by using a chisel at $1.5-2.0 \mathrm{~m}$ above ground level in order to prevent contamination by other sources of pollutants.

\section{1) Sampling of tree bark layers}

The five selected trees were located on Manee Nopparat Road $\left(18.796^{\circ} \mathrm{N} 98.981^{\circ} \mathrm{E}\right)$. This road is $2 \mathrm{~km}$ long. It is located in the business area with a high level of traffic density ( 60,000 vehicles/day) [10].

Approximately $10 \mathrm{~cm}^{2}(2 \mathrm{~cm} \times 5 \mathrm{~cm})$ of length and $15 \mathrm{~mm}$ of depth of tree bark were collected by chisel from the tree side facing the road. After that, the bark samples were separated into 4 layers from the outermost layer to the innermost layer by color differentiation, starting from gray $\left(1^{\text {st }}\right.$ layer $)$, green $\left(2^{\text {nd }}\right.$ layer $)$, red $\left(3^{\text {rd }}\right.$ layer $)$ and white brown ( $4^{\text {th }}$ layer). Factors affecting heavy metal accumulation on tree bark.

\section{2) Factors affecting heavy metal accumulation on tree bark}

\section{a) Tree exposed direction to traffic source}

Vehicle emissions are the main source of heavy metals found to be present in the atmosphere. Therefore, the sampling direction of the tree trunk facing the source of the vehicle emissions was tested. Tree bark samples $\left(4 \mathrm{~cm}^{2}\right.$ and 2 mm depth) were collected from Manee Nopparat Road. The sampling was done by collecting bark from both directly exposed sides of the tree and the opposing sides of the same tree. Five trees were selected from which 10 samples were collected.

\section{b) Size of tree trunks}

Huay Kaew Road $\left(18.805^{\circ} \mathrm{N}, 98.962^{\circ} \mathrm{E}\right)$ was selected for this study because various sizes of trees existed on this road. The traffic volume ( 40,000 vehicles/day) [10] was not found to be high when compared to Manee Nopparat Road.

Bark samples of approximately $4 \mathrm{~cm}^{2}$ and $2 \mathrm{~mm}$ depth, which were taken from the sides of the trees that were directly exposed to the road, were collected in 3 ranges of DBH (5-10 $\mathrm{cm}, 11-20 \mathrm{~cm}$ and $21-30 \mathrm{~cm}$ ) with 5 replications.

All samples were kept in polyethylene bags and stored in a refrigerator at $4^{\circ} \mathrm{C}$.

\section{Heavy Metal Analysis Methods}

The samples were dried at $60^{\circ} \mathrm{C}$ for $12 \mathrm{~h}$. The dried samples were weighed and put into the inner layer of a double layer Teflon digestion, which contained $5 \mathrm{ml}$ high purity concentrated $\mathrm{HNO}_{3}$ in the outer layer. They were digested for $4 \mathrm{~h}$ at $140{ }^{\circ} \mathrm{C}$ and diluted to $10 \mathrm{ml}$ with $0.1 \mathrm{M} \mathrm{HNO}_{3}$ and then filtered through a $0.45 \mu \mathrm{m}$ membrane. The solutions were analyzed for $\mathrm{Cr}, \mathrm{Cu}, \mathrm{Fe}, \mathrm{Ni}, \mathrm{Pb}$ and $\mathrm{Zn}$, using inductively coupled plasma optical emission spectrometry (ICP-OES).

\section{Tree Bark Morphological Characterization}

Optical microscopy was used to assess the morphological characterizations of the bark tissue. Samples of the bark layer were slided by fresh free-hand tangential sections. The plates were prepared with water and the structure was observed by light microscope. The image was recorded in digital photography format. Cell characteristics and the tissue position were used for bark layer identification.

\section{RESUlTS AND DisSUASIONS}

\section{A. Identification of Tree Bark Layer}

The layers of the bark of the selected trees were specified using both the characteristics of the cells and the position of each layer. The pictures of all layers are shown in Fig. 1. The outermost layer (gray color) was the cork layer, which is dense and has thick cell walls. The characteristics of the cells in the $2^{\text {nd }}$ layer (green color) were quite similar to the cork layer, but these cells contained the chlorophyll pigment. Therefore, the green layer consisted of chlorenchyma tissue. In the next inner layer (red layer), several cell types were present and sieve tube elements were observed. Thus, this layer was identified as the phloem layer. Cells in the innermost layer (white brown layer) consisted of ray initials and fusiform initials, which were generally present in the vascular cambium tissue. Nevertheless, the thickness of the cambium tissue is normally very thin (in $\mu \mathrm{m}$ scale) and the $4^{\text {th }}$ layer consisted of both the phloem and vascular cambium layers.

\section{B. Sampling Tree and Method}

The bark of Cassia fistula contained high amounts of $\mathrm{Fe}$ $(143 \pm 43 \mu \mathrm{g} / \mathrm{g})$ and $\mathrm{Zn}(113 \pm 18 \mu \mathrm{g} / \mathrm{g})$, as well as some amounts of $\mathrm{Cu}(8 \pm 2 \mu \mathrm{g} / \mathrm{g})$. These three elements are considered the major elements found in the brake pads and tires of vehicles. The degradation of these items was an important source of particulate heavy metals found in the emissions of these vehicles [1]. The emitted metals might be dispersed and accumulated on plants and in the soil near the roadside. Moreover, these elements were found to be the essential elements for plant growth and they were easily uptaken from the soil and extracted from the plants [11]. Therefore, the concentrations of $\mathrm{Fe}, \mathrm{Zn}$ and $\mathrm{Cu}$ were found to be high in the plants because they could be uptaken from both the soil and the ambient air. On the other hand, $\mathrm{Cr}, \mathrm{Ni}$ and $\mathrm{Pb}$ were not detected. The uptake of these elements was hindered such as the translocation of $\mathrm{Cr}$ from the roots to the shoots was intercepted by the cell wall [12]. Lead $(\mathrm{Pb})$ was found to be immobile and an easily formed organic metal complex in the soil [13]. Additionally, the Thai government had banned the use of $\mathrm{Pb}$ in gasoline since 1996, but low quantities of this element still existed in lubricants and in batteries.

With regard to the element content in each layer of the bark (Fig. 2), the trend of metal concentrations ( $\mathrm{Cu}, \mathrm{Fe}$ and $\mathrm{Zn}$ ), especially the Fe element, were highest in the cork layer and decreased in the chlorenchyma and phloem layers (inner layer) and increased again in the phloem\&vascular cambium layers. The major source of metal accumulation in the cork layer is likely a result of atmospheric pollutants because this layer is directly exposed to the environment, while the accumulation of metals in the innermost layer (phloem\&vascular cambium layer) might have been influenced by the translocation of essential elements by the vascular tissue because the location of the vascular cambium layer is connected to the xylem layer. This result was found to be related to the results of Liebergeld and team (1996) (referred by Schulz [14]), who reported that the trend of the element content of sulfur, iron and calcium in Pine bark decreased at $1.5 \mathrm{~mm}$ depth from the bark surface, then, the trend stabilized in a range of $1.5-4 \mathrm{~mm}$ and then 
increased at the deeper levels.

\section{Affecting Factors on the Accumulation of Heavy Metals}

\section{1) Tree exposed directions and heavy metal accumulation}

The concentration levels of $\mathrm{Zn}, \mathrm{Fe}$ and $\mathrm{Cu}$ are shown in Table I. It can be seen that atmospheric pollutants were equally distributed and accumulated on the tree bark because the emission sources used in this study were mobile and the emitted pollutants were easily dispersed into the area nearby. Moreover, the proximity of the trees was very close to the source of the pollutants (approximately $3 \mathrm{~m}$ ). Therefore, the amounts of heavy metals that accumulated in tree bark were almost the same for both sides.

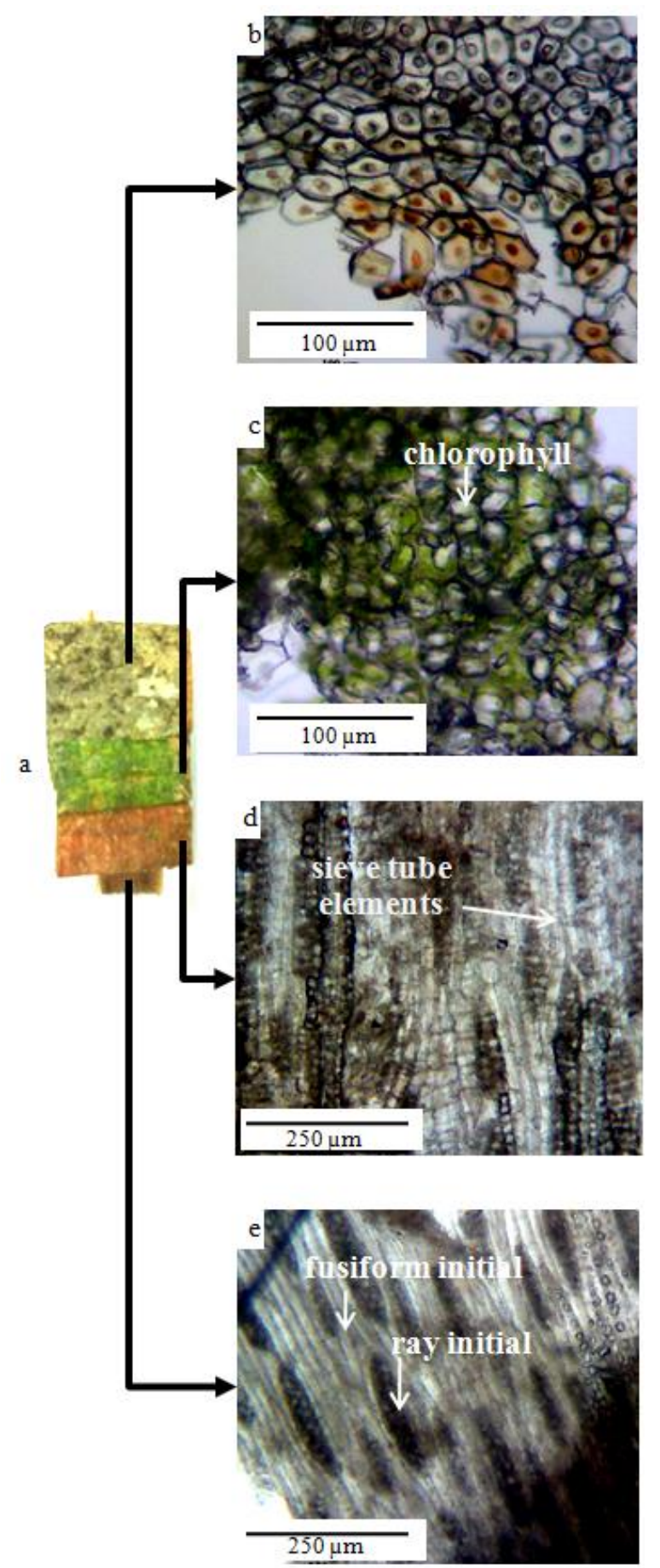

Fig. 1. Tangential section of cassia fistula bark (a) characteristics of 4 bark layers; (b) $1^{\text {st }}$ cork layer ; (c) $2^{\text {nd }}$ chlorenchyma layer; (d) $3^{\text {rd }}$ phloem layer; (e)

$4^{\text {th }}$ vascular cambium tissue in the phloem \& vascular cambium layers.

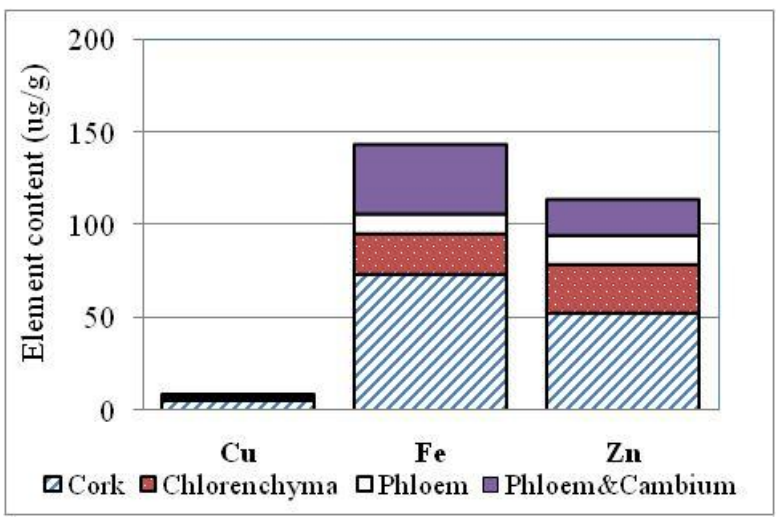

Fig. 2. Heavy metal content in each layer of Cassia fistula bark $(n=5$ samples).

TABLE I: ELEMENT CONTENT IN BARK FOR BOTH DIRECT AND INDIRECT EXPOSED SIDES TO THE ROAD (TRAFFIC SOURCE)

\begin{tabular}{cccc}
\hline \hline Direction of tree & \multicolumn{3}{c}{ Element content $(\mu \mathrm{g} / \mathrm{g})$} \\
\cline { 2 - 4 } side exposure & $\mathrm{Cu}$ & $\mathrm{Fe}$ & $\mathrm{Zn}$ \\
\hline Direct exposure & $0.85 \pm 0.17$ & $7.5 \pm 1.8$ & $24.6 \pm 3.4$ \\
Indirect exposure & $0.92 \pm 0.25$ & $7.9 \pm 1.5$ & $25.5 \pm 3.1$ \\
\hline \hline
\end{tabular}

\section{2) Tree trunk size and amount of heavy metal} accumulation

Normally, the diameter at breast height (DBH) of a tree increases with its age. The DBH ranges of the trees selected were $5-10,11-20$ and $21-30 \mathrm{~cm}$, because those ranges were the most common sizes of Cassia fistula trees found in the city. Heavy metal concentrations ( $\mathrm{Cu}, \mathrm{Fe}$ and $\mathrm{Zn}$ ) were not found to be significantly different among the DBH ranges by ANOVA test at a 95\% confidential level (Fig. 3). Thus, the DBH size expansion of Cassia fistula trees without exchange of the bark characteristics should be related to the amounts of heavy metals overall, but these amounts might be found to be similar in the units of the exposed areas.

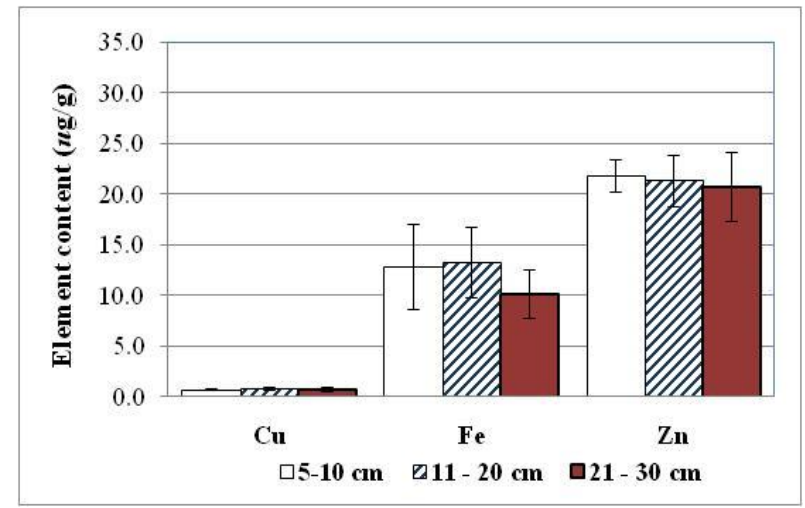

Fig. 3. Element content in tree bark with different DBH sizes.

\section{CONCLUSION}

In Cassia fistula bark samples, were found to have the highest amounts of heavy metals were found in the cork layer (outermost layer). Specific factors, including exposed directions of the tree to the source and the tree trunk size (5 $30 \mathrm{~cm}$ ) were not affected by the concentrations of heavy metals accumulated in the bark of the tree. Therefore, the use of Cassia fistula trees as a heavy metal bioindicator should be considered appropriate. However, the sampling should be done at the cork layer of the tree trunk at any size within the test range and taken from any direction of exposure. 


\section{ACKNOWLEDGMENT}

Financial support provided by Chiang Mai University and the Graduate School, Chiang Mai University are very gratefully acknowledged.

\section{REFERENCES}

[1] E. Apeagyei, S. M. Bank, and D. J. Spengler, "Distribution of heavy metals in road dust along an urban-rural gradient in Massachusetts," Atmos. Environ, vol. 45, pp. 2310-2323, 2011.

[2] C. G. Popescu, "Relation between vehicle traffic and heavy metal content from the particulate matters," Romanian Rep. Phys, vol. 63, no. 2, pp. 471-482, 2011.

[3] M. D. L. Dinis and A. Fiúza, "Exposure assessment to heavy metals in the environment: Measures to eliminate or reduce the exposure to critical receptors", Environmental Heavy Metal Pollution and Effects on Child Mental Development: Risk Assessment and Prevention Strategies, Netherlands: Springer, pp. 27-50, 2010.

[4] G. F. Fujiwara, D. R. Gomez, L. Dawidoski, P. Perelman, and A. Faggi, "Metals associated with airborne particulate matter in road dust and tree bark collected in a megacity (Buenos Aires, Argentina)," Ecol. Indic., vol. 11, pp. 240-247, 2011.

[5] Y. W. Kuang, G. Y. Zhou, D. Z. Wen, and S. Z. Liu, "Heavy metals in bark of Pinus massoniana (Lamb.) as an indicator of atmospheric deposition dear a smelter at Qujiang, China," Environ. Sci. Pollut. Res. vol. 14, no. 4, pp. 270-275, 2007.

[6] O. O. Odukoya, A. T. Arowolo, and O. Bamgbose, "Pb, $\mathrm{Zn}$, and $\mathrm{Cu}$ levels in tree barks as indicator of atmospheric pollution," Environ. Int., vol. 26, pp.11-16, 2000.

[7] E. E. Ukpebor, J. E. Ukpebor, E. Aigbokhan, I. Goji, O. A. Onojeghuo, and C. A. Okonkwo, "Delonix regia and Casuarina equisetifolia as passive biomonitors and as bioaccumulators of atmospheric trace metals," J. Environ Sc., vol. 22, no. 7, pp. 1073-1079, 2010.
[8] B. Wolterbeek, "Biomonitoring of trace element air pollution: principles, possibilities and perspectives," Environ. Pollut., vol. 120, pp. 11-21, 2002

[9] (2014). Ministry of tourism and sports. Statistic of Tourism. [Online]. Available:

http://secretary.mots.go.th/main.php?filename=76_provinces

[10] K. Sopajaree, S. Chantara, S. Koonaphapdeelert, P. Thiengburanathum, and N. Preechanukul, "The development of an emission inventory for Chiang Mai City under the clean air for smaller cities in the ASEAN region project," The Final Report to German International Cooperation (GIZ), 2011.

[11] B. J. Jones, Plant Nutrition Manual, USA: CRC Press LLC;1998.

[12] D. C. Adriano, Trace Element in Terrestrial Environments Biogeochemistry, Bioavailability, and Risks of Metals, $2^{\text {nd }}$ ed., Library of Congress Cataloging-in-Publication Data, 2001.

[13] M. N. V. Prasad, Heavy Metal Stress in Plants from Biomolecules to Ecosystems, $1^{\text {st }}$ ed., German: Springer-Verlang Berlin Heidelberg, 1999.

[14] H, Schulz, P, Popp, G. Huhn, H. J. Stark, and G. Schuurmann, "Biomonitoring of airborne inorganic and organic pollutants by means of pine tree barks. I. Temporal and spatial variations," Sci Total Environ., vol. 232, pp. 49-58, 1999.

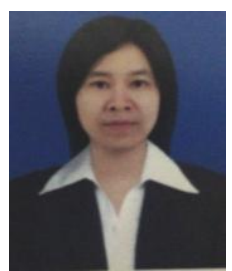

Rungruang Janta was born in Chiang Mai province, Thailand in 1981. Her educational background was bachelor degree in science program from Chiang Mai University (CMU), Thailand in 2004. Her master degree was in industrial engineering from $\mathrm{CMU}$, Thailand in 2007. Now, she is a Ph.D. student of environmental science program at CMU. Her research contributions in the field of environmental analytical chemistry. She has been in using tree as bioindicator of metals emitted from transportation. She is interested in biological monitoring. Ms. Rungruang is a member of Environmental Chemistry Research Laboratory (ECRL) since 2011 and a member of student. 